\title{
Cushing's disease: pathobiology, diagnosis, and management
}

\author{
Russell R. Lonser, MD, ${ }^{1}$ Lynnette Nieman, MD, ${ }^{2}$ and Edward H. Oldfield, MD³ \\ ${ }^{1}$ Department of Neurological Surgery, The Ohio State University Wexner Medical Center, Columbus, Ohio; ${ }^{2}$ Program in \\ Reproductive and Adult Endocrinology, Eunice Kennedy Shriver National Institute of Child Health and Human Development, \\ National Institutes of Health, Bethesda, Maryland; and ${ }^{3}$ Department of Neurological Surgery, University of Virginia Health \\ System, Charlottesville, Virginia
}

\begin{abstract}
Cushing's disease (CD) is the result of excess secretion of adrenocorticotropic hormone (ACTH) by a benign monoclonal pituitary adenoma. The excessive secretion of ACTH stimulates secretion of cortisol by the adrenal glands, resulting in supraphysiological levels of circulating cortisol. The pathophysiological levels of cortisol are associated with hypertension, diabetes, obesity, and early death. Successful resection of the CD-associated ACTH-secreting pituitary adenoma is the treatment of choice and results in immediate biochemical remission with preservation of pituitary function. Accurate and early identification of CD is critical for effective surgical management and optimal prognosis. The authors review the current pathophysiological principles, diagnostic methods, and management of CD.
\end{abstract}

http://thejns.org/doi/abs/10.3171/2016.1.JNS152119

KEY WORDS Cushing's disease; diagnosis; surgery; treatment; oncology

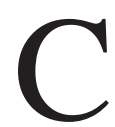

usHING's syndrome (CS) is caused by prolonged supraphysiological levels of circulating cortisol. Cushing's disease (CD) is the most common etiology (70\%-80\% of CS cases) of endogenous CS. It is caused by a pituitary adenoma that secretes adrenocorticotropic hormone (ACTH), which stimulates secretion of cortisol by the adrenal glands. If not effectively treated, $\mathrm{CD}$ is associated with hypertension, diabetes, obesity, osteoporosis, vascular disease, and shortened life span. Successful resection of a $\mathrm{CD}$-associated $\mathrm{ACTH}$-secreting pituitary adenoma results in immediate biochemical remission and preservation of pituitary function. Early identification of CD by clinical findings, endocrinological evaluation, and imaging studies is critical for diagnosis and effective surgical management.

\section{Endocrinological and Clinical Features Endocrinological Features Normal Physiology}

Insight into the normal and pathophysiological mechanisms of control of the hypothalamic-anterior pituitaryadrenal axis is critical to understanding the pathologic, di- agnostic, and therapeutic features of CD (Fig. 1). ${ }^{52}$ Under normal physiological conditions (circadian rhythm, where cortisol levels peak in early morning and nadir late at night), systemic inflammation (cytokine), or stress (physiological or psychological), corticotropin-releasing hormone (CRH; a 41-amino acid peptide) is released from the paraventricular hypothalamic nucleus via the median eminence. From the median eminence, CRH is transported in the hypophyseal portal venous system to the pituitary gland, where it binds to the CRH receptor-1 (CRH-R1) on pituitary corticotroph cells. CRH binding to CRH-R1 receptors activates adenylate cyclase and stimulates proopiomelanocortin (POMC) gene expression in the corticotroph cells..$^{17,66}$ Proopiomelanocortin preprohormone is processed into ACTH (a 39amino acid peptide) and $\beta$-lipotropin (a 93-amino acid peptide). Products of $\beta$-lipotropin include $\beta$-endorphin and $\alpha$-lipotropin. ACTH is secreted into the systemic circulation and binds to receptors in the adrenal cortex, where it stimulates production and secretion of glucocorticoids, including cortisol. ${ }^{83}$ Under normal conditions, circulating cortisol provides physiological control of this endocrine axis by its negative feedback inhibition on hypothalamic $\mathrm{CRH}$ and pituitary ACTH secretion. ${ }^{106}$

ABBREVIATIONS ATCH = adrenocorticotropic hormone; $\mathrm{CD}=$ Cushing's disease; $\mathrm{CRH}=$ corticotropin-releasing hormone; $\mathrm{CRH}-\mathrm{R} 1$ = $\mathrm{CRH}$ receptor-1; CS = Cushing's syndrome; IPSS = inferior petrosal sinus sampling; SPGR = spoiled gradient recalled; SRS = stereotactic radiosurgery.

SUBMITTED November 9, 2015. ACCEPTED January 18, 2016.

INCLUDE WHEN CITING Published online April 22, 2016; DOI: 10.3171/2016.1.JNS152119. 


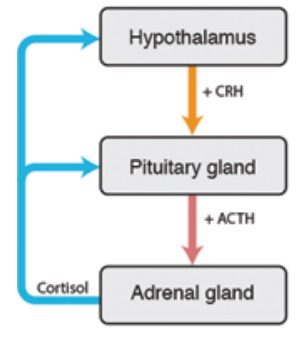

Normal

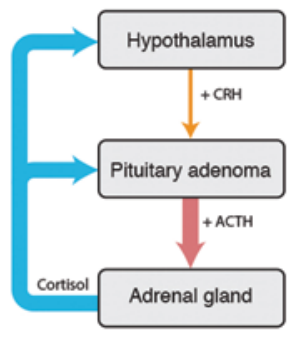

Cushing's Disease

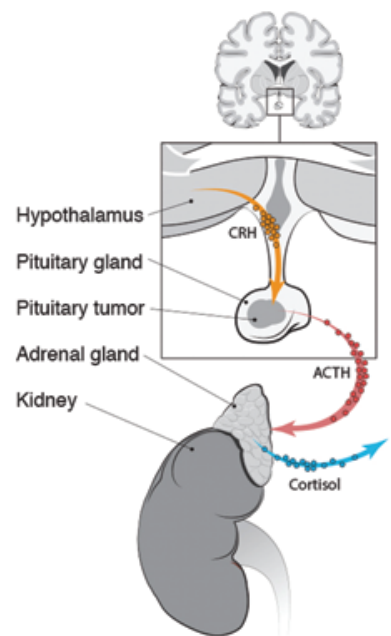

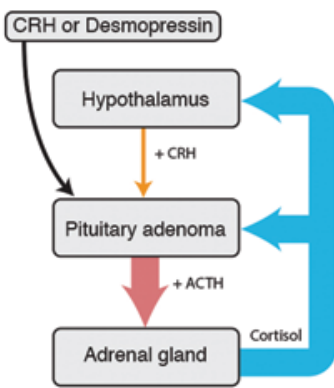

Stimulation

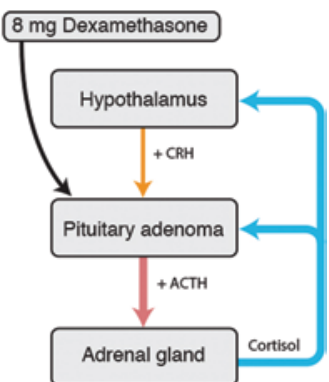

Suppression

FIG. 1. Hypothalamic-pituitary-adrenal axis in healthy individuals and CD patients. Left: Under normal physiological circumstances, including circadian rhythm (diurnal secretion that peaks in early morning and nadirs near midnight) and stress (physiological and psychological), the paraventricular nucleus of the hypothalamus releases $\mathrm{CRH}$ (orange arrows), which the hypophyseal portal venous system transports to the anterior pituitary gland. In the pituitary gland, CRH stimulates pituitary corticotroph cells (orange arrow) by binding to $\mathrm{CRH}-\mathrm{R} 1$ receptors to stimulate production and excretion of ACTH into the systemic circulation. ACTH then stimulates the adrenal cortex (red arrow) to synthesize and excrete glucocorticoids, including cortisol. Cortisol inhibits this endocrine axis (blue arrows) at the hypothalamus and pituitary by binding to glucocorticoid receptors and reducing $\mathrm{CRH}$ and ACTH production/secretion, respectively. Right: Under the pathophysiological conditions associated with CD, a benign monoclonal basophilic adenoma of the anterior pituitary gland continuously (resulting in loss of normal diurnal secretory rhythm) secretes excess levels of ACTH (large red arrow). Circulating ACTH drives supraphysiological production and secretion of cortisol from the adrenal cortices (large blue arrows) that results in reduced $\mathrm{CRH}$ production/excretion by the hypothalamus. While the ACTH-secreting adenomas in $\mathrm{CD}$ retain $\mathrm{CRH}-\mathrm{R} 1$ and vasopressin receptors with their associated stimulatory capacity (adenomas secrete ACTH [large red arrow] when stimulated by CRH or desmopressin [large blue arrows]), the cortisol-driven negative feedback on the pituitary is significantly blunted. Nevertheless, very high levels of exogenous steroid (e.g., high-dose dexamethasone test response) suppress ACTH production by CD adenomas (small red arrow) and downstream circulating cortisol levels (small blue arrows). Copyright OSU Health Sciences Library Medical Visuals. Published with permission.

\section{Pathophysiology}

$\mathrm{CD}$ is caused by a benign monoclonal pituitary corticotroph adenoma that secretes excessive $\mathrm{ACTH},{ }^{39}$ which causes supraphysiological secretion of glucocorticoids from the adrenal glands. The excess circulating cortisol disrupts the normal physiological diurnal variation in cortisol levels and exerts negative feedback inhibition on CRH secretion from the hypothalamus. However, the adenoma itself is relatively resistant to inhibition by endogenous circulating cortisol (Fig. 1). Consequently, CD is associated with suppressed secretion of CRH and elevated levels of $\mathrm{ACTH}$ in relation to the degree of cortisol production.

\section{Clinical Features Epidemiology}

CD has a prevalence of 39.1 per million inhabitants (incidence 1.2-2.4 newly diagnosed cases per 1 million persons per year). ${ }^{31,55}$ The average age at diagnosis for adults is in the 4th decade (younger in females [mean 30.5 years] than males [mean 37.1 years]). The average age at diagnosis in pediatric CD is approximately 13 years (symptom onset 10.6 years). ${ }^{50,58,60}$ Symptom initiation to diagnosis averages $2-3$ years in pediatric and adult cases. ${ }^{58,113} \mathrm{Be}-$ fore puberty, the ratio of female-to-male cases is similar (1:1). ${ }^{50,58}$ In adult CD patients, females are more frequently affected than males (3:1 vs $5: 1)^{70,82,105,113}$

\section{Clinical Findings}

Prolonged excessive cortisol exposure leads to multisystem signs and symptoms. The most common clinical features in adults include obesity, diabetes, hypertension, moon facies, and facial plethora (Fig. 2). $\cdot^{70,82}$ While the most common findings in prepubertal pediatric patients include rapid weight gain, obesity, and decreased linear growth, the most common findings in postpubertal pediatric patients are rapid weight gain, dorsal/subclavicular fat pads, and amenorrhea. ${ }^{50,58,60,100}$ Psychiatric deficits (depression, emotional liability, anxiety, psychosis, panic attacks, suicidal ideation, and paranoia) and neurocognitive deficits (learning impairment and memory deficits) can also be associated with CD and may be the only sign/ symptom in a subset of patients. ${ }^{51,69}$

\section{CD-Associated Morbidity and Mortality}

CD-associated morbidity includes cardiac and cerebrovascular events, immunosuppression, osteoporosis, psychiatric disturbances, and diabetes. Untreated CD has an estimated standardized mortality ratio (ratio of observed CD-related deaths to expected deaths in the general population) of $1.9-4.8 .^{21,31,40,55,111} \mathrm{CD}$-associated morbid risk factors are substantially reduced with successful treatment, , $1,42,102$ but effectively treated patients may have a higher frequency of diabetes, obesity, and dyslipidemia 


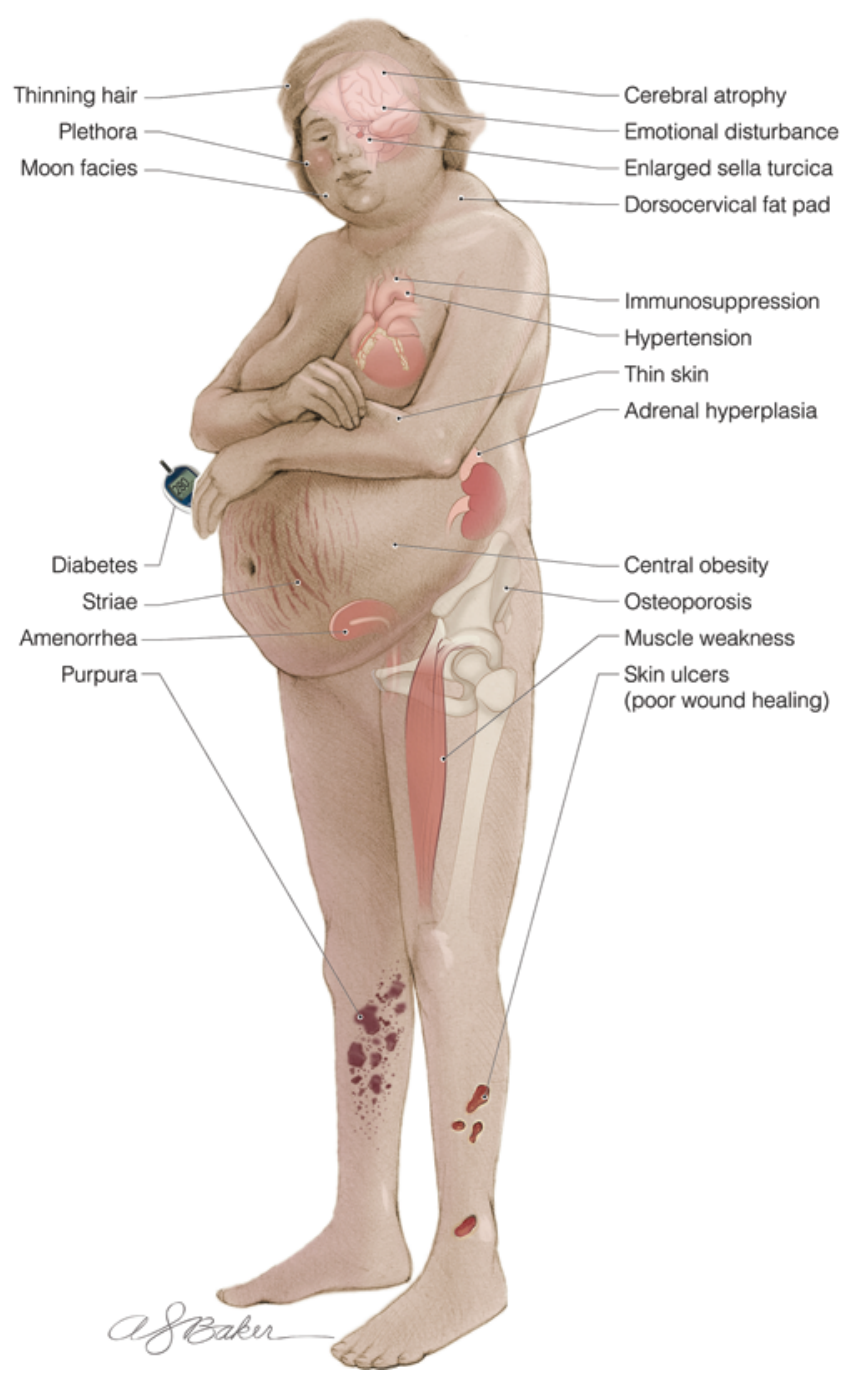

FIG. 2. Clinical features of $C D$. The hypercortisolism associated with $C D$ leads to potent clinical signs and symptoms. Common signs and symptoms in adults include weight gain, obesity, diabetes, facial plethora, moon facies, menstrual irregularities, and hirsutism. Common prepubertal signs and symptoms in pediatric patients include rapid weight gain, obesity, and decreased linear growth. The most common postpubertal signs and symptoms in pediatric patients include rapid weight gain, dorsal/subclavicular fat pad, and amenorrhea. Copyright OSU Health Sciences Library Medical Visuals. Published with permission.

compared with controls. While many studies indicate that $\mathrm{CD}$-associated mortality is returned to general population rates after biochemical remission, ${ }^{21,42,102}$ other studies have shown an elevated cardiovascular risk of death up to 5 years after successful biochemical remission. Psychiatric and neurocognitive disturbances can persistent in some patients after successful treatment. ${ }^{4,23,37,69,87}$ Patients with persistent CD after treatment suffer increased morbidity and mortality. ${ }^{42,103}$

\section{Diagnosis}

\section{Biochemical Diagnosis}

Diagnosis of CS

After exogenous sources are ruled out, clinical suspi- cion of CS leads to laboratory assessment to confirm the presence of endogenous hypercortisolism (Fig. 3). Established guidelines for the diagnosis of CS recommend verification of hypercortisolism by 2 screening tests. Screening tests include late night salivary cortisol, 24-hour urine free cortisol, or low-dose dexamethasone suppression (1 $\mathrm{mg}$ overnight or $2 \mathrm{mg}$ over 48 hours) testing. ${ }^{72}$

\section{Establishing the Cause of Hypercortisolism}

After the diagnosis of CS is established, its cause is sought. Endogenous hypercortisolism can be caused by either an ACTH-dependent (pituitary adenoma or ectopic tumor) or independent (adrenal tumor) mechanism (Fig. 3) ${ }^{6,70}$ Plasma ACTH levels are obtained to assess for ACTH dependency as the cause of hypercortisolism. Inappropriately elevated ACTH levels in a hypercortisolemic state (i.e., greater than $10 \mathrm{pg} / \mathrm{ml}$ ) are consistent with an ACTH-dependent cause (Fig. 3).

After the isolation, sequencing, and synthesis of $\mathrm{CRH}$ by Vale and colleagues in $1983,{ }^{106} \mathrm{CRH}$ stimulation was introduced as a diagnostic test for the differential diagnosis of ACTH-dependent causes of CS (Fig. 1). ${ }^{19,43,70,73,78}$ This strategy was based on the assumption that $\mathrm{CD}$ is caused by well-differentiated adenomas derived from pituitary corticotrophs and that these adenomas should have receptors for $\mathrm{CRH}$ and the cellular constituents necessary to respond to CRH stimulation (a positive response is set arbitrarily at a $50 \%$ or more increase in ACTH and $20 \%$ or more increase in cortisol). Alternatively, ectopic ACTH-secreting tumors are derived from nonpituitary tissues and generally do not respond to $\mathrm{CRH}$. However, there is an approximately $10 \%$ incidence of false-negative and false-positive results in ectopic tumors with $\mathrm{CRH}$ stimulation testing. ${ }^{43,73}$

High-dose dexamethasone suppression testing also can be used to distinguish between ACTH-dependent causes of CS..$^{19,43,54,70,73}$ Similar to the biological basis for CRH stimulation testing, dexamethasone suppression testing takes advantage of the presence of cellular constituents necessary to respond to dexamethasone (suppression) in the pituitary adenoma corticotroph cells and the lack of the negative feedback response in ectopic nonpituitary tumors that secrete ACTH (Fig. 1). In this manner, high doses $(8 \mathrm{mg}$ ) of dexamethasone can suppress cortisol (i.e., a $50 \%$ or more decrease) secretion in approximately $80 \%$ of $\mathrm{CD}$ patients but the majority of ectopic ACTH-secreting tumors typically do not respond. However, a significant overlap in responses of pituitary and ectopic tumors to high-dose dexamethasone suppression testing compromise the diagnostic accuracy of this test..$^{34,43,73}$

\section{MR Imaging}

Because of their potent biological/clinical effects, CDassociated pituitary adenomas are often discovered when they are small. Data from large surgical series indicate that over $90 \%$ of ACTH-adenomas are microadenomas ( $<$ $1 \mathrm{~cm}$ in diameter) with a mean diameter of $6 \mathrm{~mm}$ at time of diagnosis. ${ }^{46,58}$ However, the small adenoma size and a reduced signal-to-noise imaging ratio at the sella-sphenoid bone-air interface contribute to the $40 \%-60 \%$ lack of detection of CD-associated adenomas on MR imaging at time of clinical and biochemical diagnosis. ${ }^{20,46}$ To best 


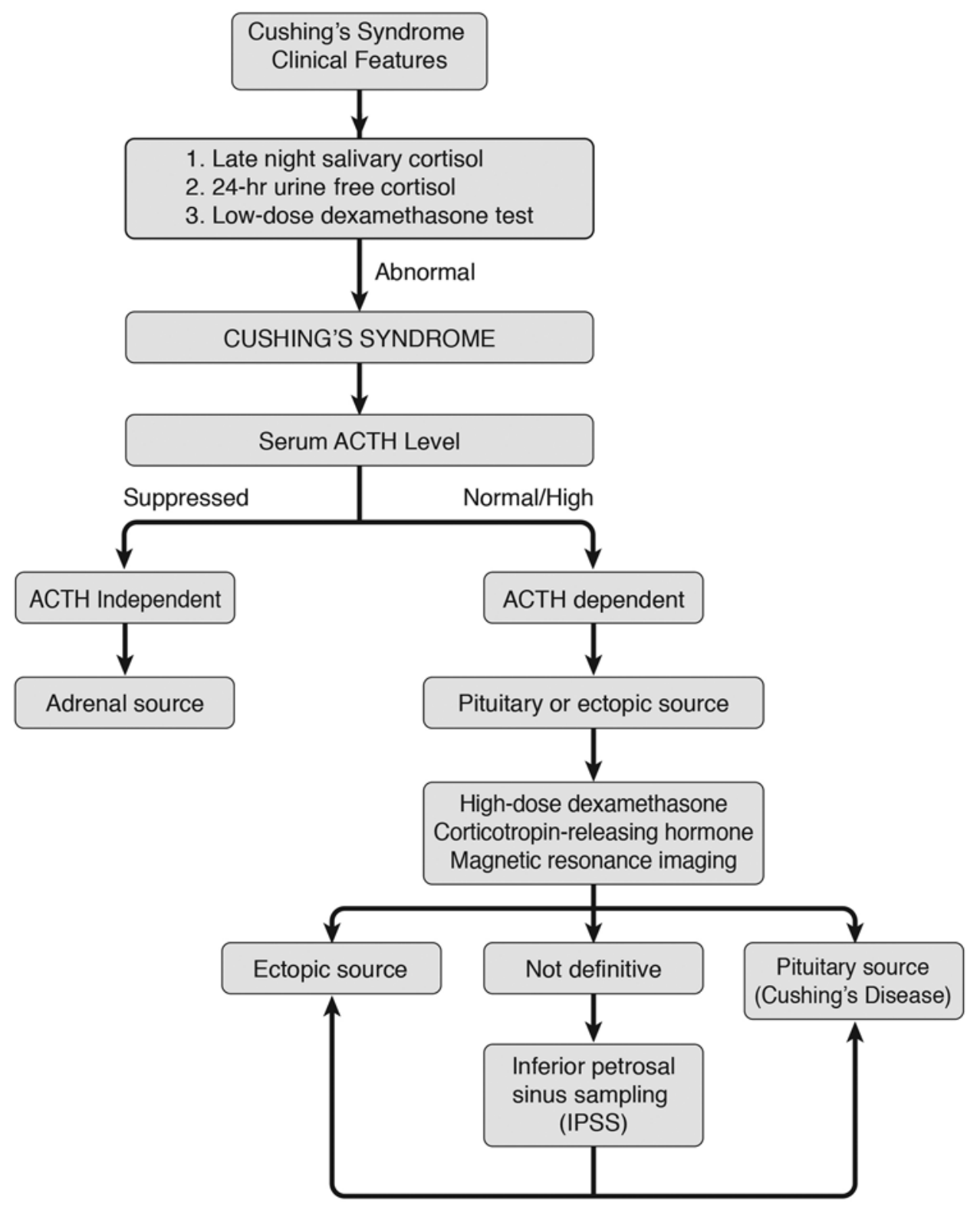

FIG. 3. Diagnostic assessment of hypercortisolism. CS diagnostic testing: Guidelines for assessment of cortisol production in patients with clinical features of hypercortisolism (CS) advocate measurement of late-night salivary cortisol, 24-hour urine free cortisol, or low-dose dexamethasone suppression testing (1 mg overnight or $2 \mathrm{mg}$ over 48 hours). Elevated levels of cortisol by these screening tests are consistent with CS. CS differential diagnostic testing: ACTH levels distinguish between ACTH-independent and ACTH-dependent causes of CS. Suppressed levels of ACTH are consistent with ACTH-independent causes (approximately $15 \%-20 \%$ of CS patients). ACTH-independent etiologies include adrenal adenomas, adrenal carcinomas, or adrenal hyperplasia, and are delineated by CT or MR imaging of the adrenal glands. Normal or elevated levels of ACTH are consistent with ACTH-dependent causes of CS (70\%-80\% of cases). Cortisol suppression after high-dose dexamethasone, cortisol, and ACTH responses to $\mathrm{CRH}$ stimulation and MR imaging revealing a pituitary adenoma ( $40 \%-60 \%$ of $\mathrm{CD}$ cases) are consistent with $\mathrm{CD}$, and patients are referred for pituitary surgery. ACTH-dependent patients who do not suppress with high-dose dexamethasone suppression testing or stimulate cortisol production with $\mathrm{CRH}$ stimulation testing may have an ectopic ACTH-secreting tumor $(10 \%-15 \%$ of cases). Ectopic ACTH-secreting tumors, including pulmonary and other carcinoid tumors, can usually be detected and localized by body imaging. ACTH-dependent patients with discordant results of the noninvasive differential diagnostic tests and/or with negative pituitary MR imaging undergo inferior petrosal sinus sampling to determine if hypercortisolism is from a pituitary adenoma (CD).

detect CD-associated adenomas on MR imaging, spoiled gradient recalled (SPGR) acquisition MR sequences are used. High-resolution (1- to 1.5-mm slice thickness) SPGR
MR imaging enhances detection of ACTH-secreting pituitary adenomas by $15 \%-30 \%$ compared with other available MR imaging sequences (Fig. 4). 


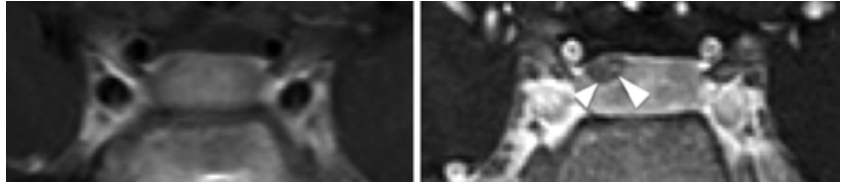

FIG. 4. Coronal postcontrast MR images of the pituitary gland in a 6-year-old boy with CD. Preoperatively, standard T1-weighted (left) and SPGR MR (right) images were performed. While T1-weighted MR imaging did not reveal an adenoma, SPGR MR imaging clearly demonstrates a 3-mm adenoma (right, arrowheads). At surgery, an adenoma was found precisely in the location revealed by SPGR MR imaging. Complete resection was achieved, resulting in biochemical remission.

\section{Inferior Petrosal Sinus Sampling \\ Diagnostic Evaluation}

The pituitary gland drains laterally into the cavernous sinuses and then into the inferior petrosal sinuses. ACTH has a short half-life that results in an ACTH concentration gradient between the inferior petrosal veins and the peripheral blood. Consequently, more concentrated blood can be sampled from the direct venous drainage of the pituitary (via the inferior petrosal veins) compared with sampling from the systemic venous system. To better enhance central to peripheral differences in pituitary secretory substances (including ACTH), CRH stimulation was introduced during inferior petrosal sinus sampling (IPSS). Combining IPSS with CRH simulation reduced the incidence of false-negative findings compared with systemic sampling. ${ }^{73}$

Since the cavernous sinus blood often remains on one side as it enters the petrosal venous system, sampling from only one petrosal sinus has limited diagnostic utility. ${ }^{28,34,75}$ A combination of facts (i.e., the increased sensitivity of detecting ACTH secretion from a corticotroph adenoma, the stimulation response of the adenoma to $\mathrm{CRH}$, and the potential for the venous blood to remain on one side of the inferior petrosal sinus in many patients) leads to the introduction of CRH stimulation with bilateral simultaneous IPSS for the differential diagnosis of CS. Furthermore, because of the frequent ipsilateral lateralization of pituitary gland drainage, lateralization of ACTH concentration in the inferior petrosal sinuses identified by bilateral assessment can also assist in the lateralization of adenoma within the pituitary gland in some cases (see IPSS Lateralization for Localization of ACTH Adenomas in $C D$ below). ${ }^{34,75}$

While false-negative and false-positive results are associated with IPSS, most diagnostic errors with IPSS are false-negative results in $C D$ patients who do not have a central-to-peripheral concentration gradient (ratio of central-to-peripheral ACTH levels) of basal ACTH that is 2.0 or more, or 3.0 or more after CRH stimulation. $33,45,80,93,110$ This is often a result of unsuccessful placement of the intravascular catheter tips in the inferior petrosal sinuses. To avoid this problem, proper placement of intravascular catheter tips can be routinely confirmed by retrograde venography of the cavernous sinuses and inferior petrosal sinuses. The consistency of success with bilateral sampling of the inferior petrosal sinuses is operator dependent and varies substantially from center to center, from nearly uni- versal success at some centers $33,38,110$ (including pediatric patients) to success rates of $67 \%-84 \%$ at others. ${ }^{49,96}$

Most CD patients with a false-negative result can be identified by their relatively low peak ACTH levels in the inferior petrosal sinus blood (less than $200 \mathrm{pg} / \mathrm{ml}$ basal levels or less than $400 \mathrm{pg} / \mathrm{ml}$ after CRH stimulation). ${ }^{75,110}$ The relative concentration of prolactin in the inferior petrosal sinus blood compared with the peripheral blood can be used to normalize the concentration of the ACTH from the inferior petrosal sinuses in relation to the peripheral blood to yield a calculated ACTH in the inferior petrosal sinus-to-peripheral blood ratio that can enhance the diagnostic accuracy of the test. ${ }^{33,65,93}$ For this reason, many centers save blood samples from the procedure and measure the prolactin concentrations if the results of the IPSS need further analysis. To avoid false-positive results, IPSS must be performed while the patient is hypercortisolemic. If IPSS is performed in the absence of sustained hypercortisolism, the normal corticotrophs are not suppressed and will respond to $\mathrm{CRH}$. The resulting inferior petrosal sinus-to-peripheral ACTH gradient will suggest CD, regardless of the etiology of CS and in normal subjects. ${ }^{80,112}$ Thus, during the eucortisolemic phase of cyclic CS or while under medical therapy to block cortisol production, false-positive results occur.

The initial results of IPSS for the differential diagnosis of CS suggested that the diagnostic accuracy of IPSS was $100 \%{ }^{34,75}$ However, later experience from many centers has indicated that, although the test is the most accurate endocrine test for the differential diagnosis of ACTH-dependent CS, it is now generally accepted to have a diagnostic accuracy in the range of about $95 \%$ at most institutions with a large CS experience. ${ }^{33,49,80,93}$ Although the largest experience with bilateral IPSS is with CRH stimulation, corticotroph tumors also respond to desmopressin, which can be used for the test if CRH is unavailable (Fig. 3). ${ }^{16,59}$

\section{IPSS Lateralization for Localization of ACTH Adenomas in CD}

In the first small series, it appeared that bilateral IPSS (indicated by a side-to-side basal ratio of 1.4 or more) would permit prediction of the side of the pituitary gland that contained an ACTH-secreting microadenoma. ${ }^{61,72}$ However, later experience has shown that the lateralization accuracy of the test is in the range of $70 \%{ }^{75,110}$ and the highest predictive value for lateralization is associated with consistent lateralization before and after CRH stimulation. ${ }^{110}$

\section{Complications of IPSS}

Venous infarction of the brainstem with permanent, serious neurological deficits can occur during IPSS. . $^{38,64}$ Thus, most centers of expertise in the evaluation and treatment of CS use IPSS only in patients with ACTH-dependent $\mathrm{CD}$ and conflicting results of noninvasive endocrine evaluation for the differential diagnosis of CS, discordant biochemical and radiological studies, or negative pituitary MR imaging (Fig. 3). ${ }^{80}$

\section{Cyclical CS and CD}

Since the report by Liddle and colleagues in $1973,{ }^{12}$ it 
has been apparent that the exceptionally rare patient with clinical features of CS may have cycles of excess glucocorticoid production that occurs every few days, weeks, or months. During cycles of normal cortisol production, endocrine testing to establish the diagnosis of CS or the differential diagnosis of it can be misleading. Consequently, it is important to recognize the potential diagnostic dilemma associated with such patients, especially since cyclical CS may accompany CD, ectopic ACTH-producing tumors, or cortisol-secreting adrenal tumors. The diagnostic strategy in cyclical CS is clinical follow-up with repeated testing, relying on testing midnight salivary cortisol and 24-hour urine free cortisol testing, rather than dexamethasone suppression testing. ${ }^{72}$

\section{Surgical Treatment \\ Selective Adenomectomy}

Successful adenomectomy eradicates the ACTH-secreting adenoma and immediately eliminates excess cortisol production while maintaining normal pituitary function (Fig. 5). Consequently, the initial treatment recommendation for CD is surgery. ${ }^{10,71}$ While some centers advocate medical therapy before surgery to reverse the effects of

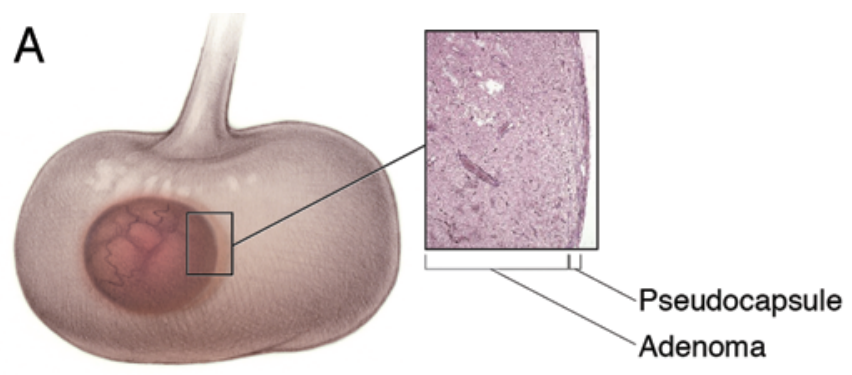

$\mathrm{B}$

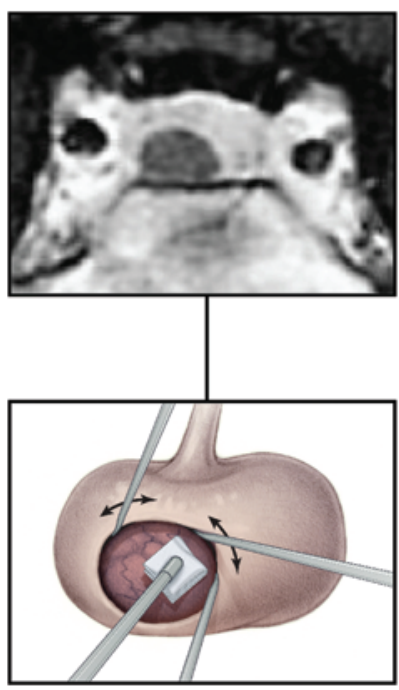

C

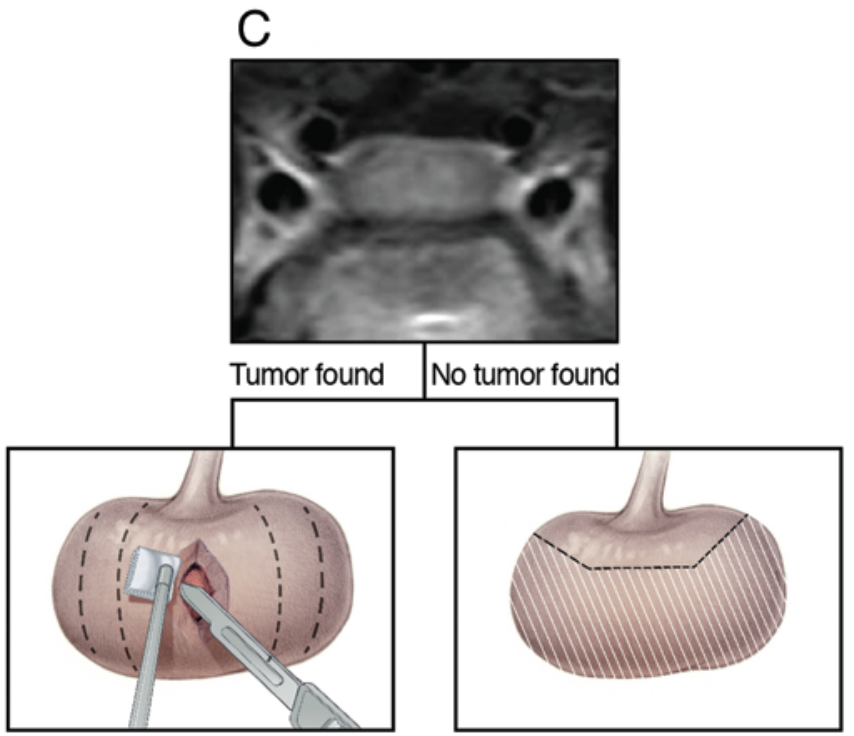

D

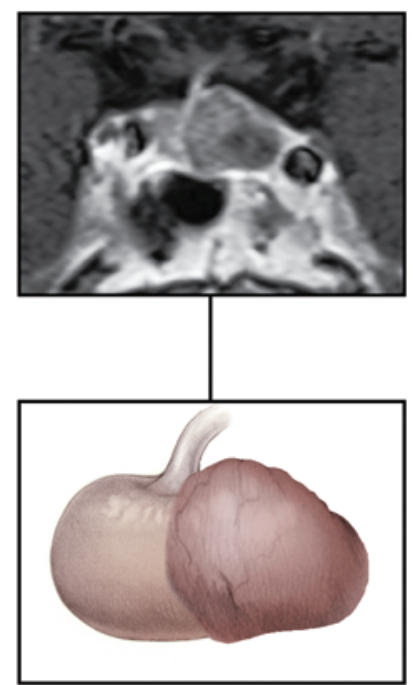

FIG. 5. Surgical management of CD. A: Once a pituitary adenoma reaches a diameter of $3 \mathrm{~mm}$, it compresses the immediately surrounding pituitary gland tissues to form a histological pseudocapsule comprising compressed pituitary gland and associated reticulin (inset). This histological feature creates a discrete tissue plane between the adenoma and normal pituitary gland that can be exploited to effectively resect small and large adenomas while minimizing injury to the surrounding pituitary gland. Several factors, including adenoma size, MR imaging findings, and dural invasion, impact the likelihood of surgical success in CD. B: The highest probability of successful resection (more than $95 \%$ of patients have biochemical remission) occurs in CD patients with adenomas that are large enough to create a peritumoral pseudocapsule, are visible on MR imaging (top) and do not invade the dural walls of a cavernous sinus. C: A number of CD cases are associated with adenomas that are not visible on MR imaging (top) and that are often small. When these tumors are large enough to form a histological pseudocapsule they can often be discovered through a series of incisions made sequentially deeper in the pituitary gland and successfully removed once they are visually identified (greater than $95 \%$ of patients in this circumstance have biochemical remission). Nevertheless, in some CD patients, an adenoma is not discovered after complete exploration of the pituitary gland, and partial (removal of $70 \%-80 \%$ of anterior pituitary gland or the half of pituitary gland that corresponds to increased ACTH levels during IPSS) or complete hypophysectomy is performed. Partial and complete hypophysectomy are associated with similar rates of biochemical remission $(60 \%-80 \%)$ but complete hypophysectomy produces loss of pituitary function. $\mathbf{D}$ : When macroadenomas (1 cm or more in diameter) occur in CD patients, they are more often associated with dural invasion. In these cases, excision of the adenoma using the histological pseudocapsule is performed and the invaded dura is selectively removed. Copyright OSU Health Sciences Library Medical Visuals. Published with permission. 
hypercortisolism, preoperative medical therapy complicates postoperative evaluation and is rarely necessary. Since 2010, surgical series generally show remission rates between $65 \%$ and $85 \%$ and recurrence rates of $10 \%-35 \%$ (Table 1). ${ }^{1-3,5,8,20,24,25,27,41,44,53,86,97,99,101,107}$ Surgical success and recurrence rates depend on surgeon experience, as well as the criteria used to define cure and length of follow-up.

\section{Factors Affecting Surgical Outcome}

Most of the emphasis on surgical technique for pituitary tumors over the past 30 years has been on approaches to the pituitary (sublabial, endonasal, endoscopic, and/or microscopic) ${ }^{62}$ instead of the details of how best to remove the tumor with most consistent success. Nevertheless, 3 factors influence the likelihood of successful surgery, including preoperative MR imaging findings, dural invasion by the adenoma, and adenoma size.

\section{Preoperative MR Imaging Findings}

Preoperative adenoma identification on MR imaging is associated with higher odds of finding the adenoma at surgery (18-fold higher) and postresection biochemical remission (4-fold). ${ }^{19}$ When an adenoma is seen on MR imaging, it directs surgical exploration to the adenoma location within the pituitary $(86 \%$ correlation between MR imaging and surgical findings). ${ }^{110} \mathrm{~A}$ critical feature associated with successful surgical treatment, cavernous sinus dural invasion, is not well detected on MR imaging. Only 22\% of cavernous sinus wall invasion cases in CD are accurately detected by MR imaging. ${ }^{57}$

An MR imaging-invisible adenoma often can be found in $\mathrm{CD}$ patients by systematic exploration of the pituitary gland via a series of incisions carried deeper in stages.7.,92 When adenomas reach a diameter of approximately $3 \mathrm{~mm}$, a surrounding microscopic tissue envelope develops that corresponds to a rim of compressed gland adjacent to the edge of the adenoma (histological pseudocapsule) that can be used to identify small adenomas and that facilitates selective enucleation of both small and large adenomas. ${ }^{46,58,77}$ Selective adenomectomy using the histological pseudo- capsule to define the boundaries of the adenoma achieves immediate and lasting remission in $97 \%$ of adult and $98 \%$ of pediatric $\mathrm{CD}$ patients. ${ }^{46,58}$

\section{Adenoma Dural Invasion}

Persistent hypercortisolism after adenoma resection can result from dural invasion, which usually occurs laterally into the cavernous sinus wall. If dural invasion is limited to partial thickness invasion of the cavernous sinus wall, invaded portions of dura can be removed safely, resulting in biochemical remission. ${ }^{26,57}$ When the adenoma extends through the dural wall and invades the cavernous sinus, lasting curative surgery is unlikely, even with apparent complete removal of the tumor from the cavernous sinus.

\section{Adenoma Size}

When adenomas are so small that they cannot be located during pituitary gland exploration, a portion (partial hypophysectomy) or all (total hypophysectomy) of the anterior lobe may be removed. Partial hypophysectomy involves either removal of $70 \%-80 \%$ of the anterior pituitary lobe, leaving $20 \%-30 \%$ attached to the pituitary stalk, or removal of half of the anterior lobe corresponding to IPSS lateralization. Partial and total hypophysectomies have similar biochemical remission rates $(60 \%$ to $80 \%$ ) (Table 2). 2,11,29,42,85,104 While partial hypophysectomy permits most patients to retain normal pituitary function, pituitary function is permanently abolished after total hypophysectomy.

\section{Risks of Surgery}

Risks of operative therapy for CD (2\%-10\% morbidity, less than $2 \%$ mortality) are similar to surgery for other pituitary tumors and include vision loss, other cranial nerve injury, vascular injury, loss of pituitary function, diabetes insipidus, delayed hemorrhage, and cerebrospinal fluid leakage. ${ }^{20,58,98}$ Because of the small size of most adenomas in $\mathrm{CD}$, these risks occur less likely than after surgery for larger pituitary tumors.

TABLE 1. Surgical results for Cushing's disease based on recent reports*

\begin{tabular}{|c|c|c|c|c|c|c|}
\hline \multirow[b]{2}{*}{ Authors \& Year } & \multirow[b]{2}{*}{ No. of Patients } & \multicolumn{3}{|c|}{ Remission } & \multirow[b]{2}{*}{ Mean Follow-Up (yrs) } & \multirow[b]{2}{*}{ Recurrence } \\
\hline & & Overall & Hypocortisolemic & Eucortisolemic & & \\
\hline Alahmadi et al., 2013 & 42 & $28(67 \%)$ & $22(79 \%)$ & $6(21 \%)$ & 2.8 & $7 \%$ \\
\hline Alexandraki et al., 2013 & 124 & $84(68 \%)$ & $56(45 \%)$ & $28(23 \%)$ & 15.9 & $24 \%$ \\
\hline Hameed et al., 2013 & 52 & $43(83 \%)$ & $13(30 \%)$ & $30(70 \%)$ & 1.4 & $14 \%$ \\
\hline Lambert et al., 2013 & 257 & $230(89 \%)$ & $195(76 \%)$ & NR & 6.3 & $21 \%$ \\
\hline Lonser et al., 2013 & 200 & $195(98 \%)$ & $189(95 \%)$ & $6(3 \%)$ & 6.8 & $7 \%$ \\
\hline Starke et al., 2013 & 61 & $58(95 \%)$ & $35(57 \%)$ & $23(38 \%)$ & 2.3 & $11 \%$ \\
\hline Wagenmakers et al., 2013 & 86 & $62(72 \%)$ & NR & NR & 5.9 & $16 \%$ \\
\hline Aranda et al., 2015 & 32 & $32(78 \%)$ & $12(38 \%)$ & $20(62 \%)$ & 14.0 & $66 \%$ \\
\hline Berker et al., 2013 & 90 & $81(90 \%)$ & $76(94 \%)$ & $5(6 \%)$ & 2.7 & $5.6 \%$ \\
\hline Costenaro et al., 2014 & 103 & $84(76 \%)$ & $34(40 \%)$ & NR & 6 & $8 \%$ \\
\hline Dimopoulou et al., 2014 & 120 & $85(71 \%)$ & $65(76 \%)$ & $20(24 \%)$ & 6.6 & $34 \%$ \\
\hline
\end{tabular}

NR = not reported.

* Adapted from Dallapiazza et al., 2015. 
TABLE 2. Results for hypophysectomy for Cushing's disease

\begin{tabular}{|c|c|c|c|c|c|c|}
\hline \multirow[b]{2}{*}{ Authors \& Year } & \multirow[b]{2}{*}{ No. of Patients } & \multirow[b]{2}{*}{ No Tumor Found } & \multicolumn{2}{|c|}{ Total Hypophysectomy } & \multicolumn{2}{|c|}{ Partial Hypophysectomy* } \\
\hline & & & Patients & Remission & Patients & Remission \\
\hline Tindall et al., 1990 & 52 & $13(25 \%)$ & 8 & $7(82.5 \%)$ & 5 & $5(100 \%)$ \\
\hline Bochicchio et al., 1995 & 668 & NR & NR & $(67 \%)$ & NR & $(76 \%)$ \\
\hline Hammer et al., 2004 & 289 & $62(21 \%)$ & 23 & $18(78 \%)$ & 25 & $23(92 \%)$ \\
\hline Esposito et al., 2006 & 40 & $9(23 \%)$ & 1 & $0(0 \%)$ & 8 & $4(50 \%)$ \\
\hline Pouratian et al., 2007 & 445 & $111(25 \%)$ & 28 & $14(50 \%)$ & 49 & $26(53 \%)$ \\
\hline Alexandraki et al., 2013 & 83 & NR & 26 & $15(58 \%)$ & 22 & $15(68 \%)$ \\
\hline Total & 826 & $195(24 \%)$ & 86 & $54(63 \%)$ & 109 & $73(67 \%)$ \\
\hline
\end{tabular}

* Hemihypophysectomy or partial hypophysectomy.

\section{Absence of Hypocortisolism After Surgery}

Within 48 hours of surgery, most patients in remission from CD develop a glucocorticoid withdrawal syndrome associated with circulating cortisol levels of $2 \mu \mathrm{g} / \mathrm{dl}$ or less (see Measures of Biochemical Remission below). Alternatively, with persistence of hypercortisolism after surgery, the source of the unsuccessful surgery must be residual tumor that was not removed. Four factors influence incomplete tumor removal: 1) the removal of incidental adenomas (which occur in 15\%-20\% of pituitaries at autopsy but for unexplained reasons are much less likely to occur during surgical exploration in $\mathrm{CD}$ ) rather than the corticotroph tumor(s) can occur; ${ }^{59}$ 2) mistakenly assuming an adenoma was found, resulting in the removal of a site that appears abnormal at surgery, but that proves to be normal gland on histological inspection; 3) incomplete removal of an ACTH-secreting adenoma contained within the pituitary; and 4) an invasive ACTH-secreting adenoma that was not recognized or incompletely removed at surgery can result in lack of biochemical remission. ${ }^{26,57}$

The first 2 causes of incomplete ACTH-secreting adenoma removal often occur in patients when complete exploration of the gland was not performed after the apparent adenoma was removed (Fig. 6). Early repeat surgery is an option in these cases with exploration of the unexplored portion of the pituitary in an attempt to find and remove the adenoma, or removal of a portion of the remaining anterior lobe if no tumor can be identified, as described above. If an ACTH-staining adenoma contained completely within the pituitary gland was identified but only partially removed at the initial surgery, the residual tumor is always in the same region. Repeat surgery offers an excellent chance of complete resection in these cases. Thus, early repeat surgery has a reasonable chance of curing the condition and preserving pituitary function in the first three circumstances. ${ }^{9,88,95} \mathrm{On}$ the other hand, if the gland was completely explored at the initial surgery by an experienced surgeon, the chances of achieving remission by finding and selectively excising an ACTH-producing adenoma are remote. Additional surgery is rarely indicated in this circumstance.

\section{Recurrence of CD After Initial Surgical Remission}

Delayed (months to years after initial biochemical remission) $\mathrm{CD}$ recurrence represents growth of residual microscopic tumor at the site, or immediately adjacent to the adenoma resection site at the initial operation (Fig. 6). Similar to initial surgery, identification of recurrent adenoma on MR imaging guides surgery to the site of adenoma and predicts success of repeat surgery for recurrent CD.

\section{Measures of Biochemical Remission}

Determinates of lasting biochemical remission have not been defined. A variety of posttreatment criteria have been used to assess therapeutic success. Specifically, low (below $2 \mu \mathrm{g} / \mathrm{dl}$ ) morning serum cortisol, low urine free cortisol levels (below $20 \mu \mathrm{g} / 24$ hours), low serum ACTH (less than $5 \mathrm{pg} / \mathrm{ml}$ ), and/or low midnight salivary cortisol within the 1st week have been used to predict lasting success. ${ }^{10,14,56,58}$ Recent data indicate that a morning serum cortisol level less than $1 \mu \mathrm{g} / \mathrm{dl}$ (on postoperative Day 3, 4, or 5 off of exogenous steroids) is the best predictor of lasting biochemical remission (96\% positive predictive value). However, higher subnormal values do not exclude lasting remission. Dynamic testing, including CRH or desmopressin stimulation testing, can be used to predict biochemical remission but have not proven to be more effective in predicting longterm remission than basal serum cortisol levels.

\section{Postsurgical Endocrinological Management}

Hypocortisolism occurs after successful adenomectomy and reflects suppression of the normal pituitary corticotrophs by long-standing hypercortisolism. Typically, the suppressed normal pituitary gland corticotrophs in the hypothalamic-pituitary-adrenal axis typically do not recover normal function for 6-12 months. During this time, patients receive physiological glucocorticoid replacement (typically, hydrocortisone $10-12 \mathrm{mg} / \mathrm{m}^{2}$ daily, given twothirds in the morning and one-third in the afternoon). Restoration of hypothalamic-pituitary-adrenal axis function is assessed by return of normal morning cortisol levels (greater than $18 \mu \mathrm{g} / \mathrm{dl}$ ) and/or a normal cortisol response to ACTH-stimulation. Hydrocortisone is then discontinued.

While the goal of adenoma resection is to preserve normal pituitary tissue and function, hypopituitarism occasionally occurs (less than 5\%). ${ }^{20,58,85,92}$ Pituitary function is assessed within 2 weeks of surgery by measuring total $\mathrm{T}_{4}$ and prolactin. If $\mathrm{T}_{4}$ is similar to preoperative values and prolactin is greater than $4 \mathrm{ng} / \mathrm{ml}$, the pituitary is considered functional. Characteristic CS-associated hypogonad- 


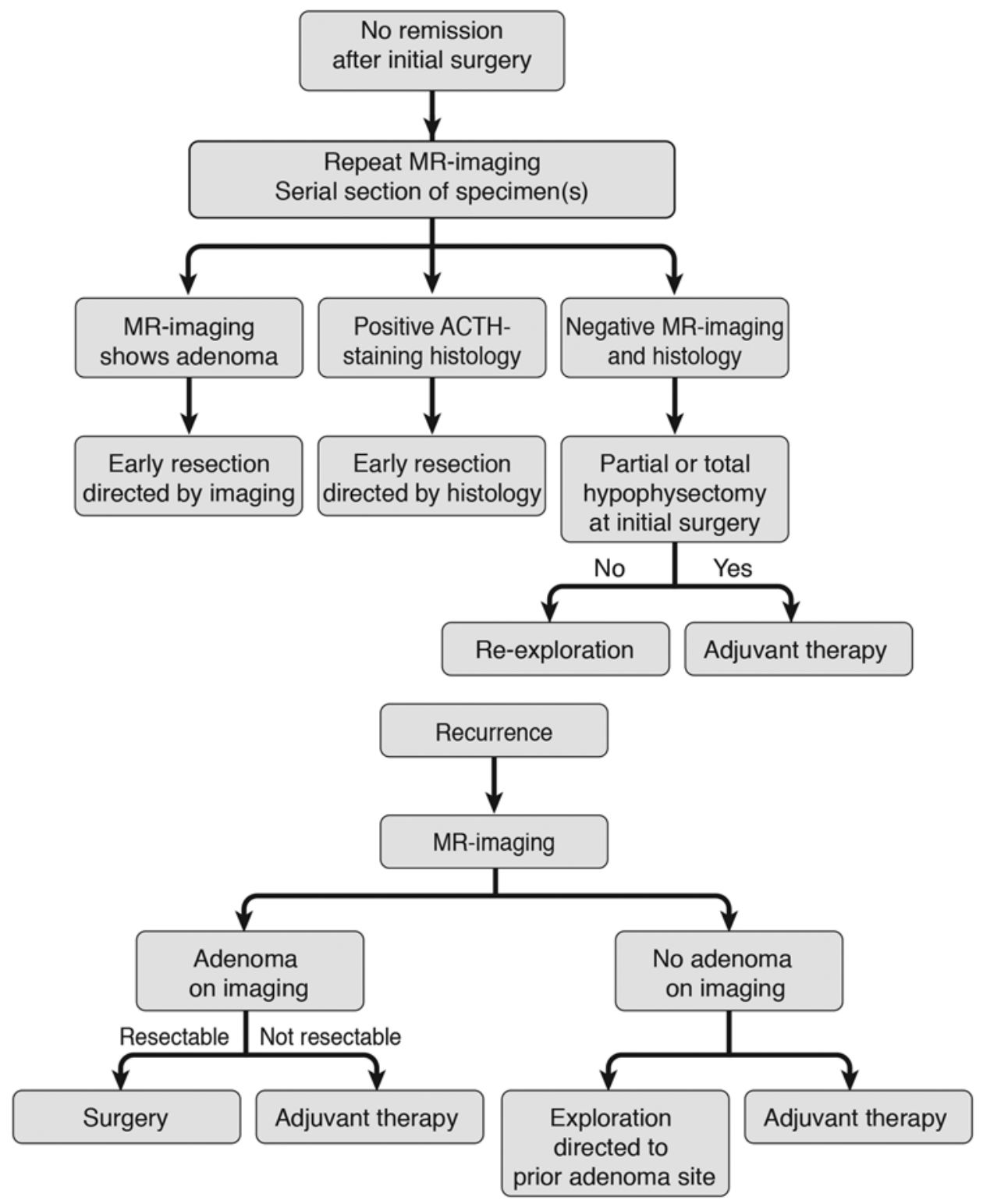

FIG. 6. Management of CD in the absence of hypocortisolism after initial surgery (upper) and recurrence of after initial surgical remission (lower). Upper: Lack of biochemical remission after initial surgery is evaluated by early repeat pituitary MR imaging and detailed serial histological evaluation of specimens received from surgery. If MR imaging demonstrates an adenoma, early resection (within 3 weeks) directed by the imaging findings is performed. If ACTH staining is discovered on histological analysis, early resection directed by histological findings is performed. If MR imaging and histology findings are negative for evidence of $C D$, and hypophysectomy (partial or total) was not performed at initial surgery, then reexploration of the pituitary gland is performed. If hypophysectomy (partial or total) was performed at initial surgery, then adjuvant therapies are used to control CD. Lower: If recurrence of CD occurs after initial surgical remission, pituitary MR imaging is performed. If MR imaging reveals an adenoma that is resectable, surgery is performed to remove the adenoma. If the adenoma does not appear to be resectable on MR imaging, adjuvant therapy is used to control CD. If no adenoma is apparent on MR imaging, surgical exploration directed to the site of prior adenoma location is performed or adjuvant therapy is employed if features from prior surgery or patient condition preclude additional surgical exploration.

ism, relative hypothyroidism, and low growth hormone dynamics resolve slowly over $6-12$ months. Treatment for these endocrinological changes is individualized according to patient age and symptoms.

\section{Pathologic Findings}

Harvey Cushing originally described the adenomas as- sociated with $\mathrm{CD}$ as basophilic adenomas. Immunohistochemistry of CD adenomas shows diffuse ACTH-positive tumor cells. Because complete adenoma removal results in profound hypocortisolism (24-48 hours after surgery in most patients), it seems counterintuitive that the normal pituitary gland corticotrophs would retain normal ACTH-positive staining. Nevertheless, the normal gland corticotrophs do maintain ACTH-positive staining in CD. 
At centers that infrequently deal with CD patients, ACTHpositive staining of the normal pituitary gland corticotrophs can occasionally lead to an incorrect diagnosis of diffuse corticotroph hyperplasia. In turn, this can lead to total hypophysectomy if it is not recognized as the normal pattern of staining in the normal gland in CD patients. In a series of more than 1500 patients with $C D$, we have not encountered a case of diffuse corticotroph hyperplasia in the absence of ectopic production of CRH (a very rare cause of $\mathrm{CD}$ that is associated with corticotroph hyperplasia).

In 75\%-80\% patients with chronic hypercortisolism of any etiology, the normal corticotrophs undergo changes in which the cytoplasmic granules are replaced with homogeneous hyaline material. These changes are histological changes known as Crooke's changes. ${ }^{76}$ The presence of these changes is associated with the degree of hypercortisolism and individual susceptibility to them. The changes are never present in the absence of hypercortisolism. Consequently, their presence can be used to confirm that a patient in whom no signs of CS were seen on surgical exploration of the pituitary does, indeed, have CS. On the other hand, about $20 \%$ of patients with an ACTH-positive staining pituitary adenoma at surgery do not have Crooke's changes and, therefore, the absence of Crooke's changes does not establish the absence of CS. ${ }^{76}$

\section{Other Treatments Medical Therapy}

Medical therapy is the standard second-line treatment if surgery is not successful or if it is not possible. In these circumstances, medical therapy may be used adjunctively with radiation therapy to achieve eucortisolism while awaiting the therapeutic effects of radiation. Effectiveness of medical therapy (usually assessed by normalization of urine free cortisol levels) should be established before initiation of radiation treatment to avoid hypercortisolemia while waiting for the effects of radiation. Medical therapies include steroidogenesis inhibitors, corticotroph-directed agents, and glucocorticoid receptor blockers.

\section{Steroidogenesis Inhibitors}

Steroidogenesis inhibitors, mitotane, ketoconazole, metyrapone, and etomidate block one or more steps of adrenal steroidogenesis of cortisol. Mitotane is typically not a firstline agent because the high rate of gastrointestinal side effects, long onset to action, and its teratogenic/abortifacient effects in women who desire pregnancy. Recently, a large retrospective study (200 patients) revealed that $49 \%$ of CD patients treated with ketoconazole achieved normalization of urine free cortisol levels (an additional 26\% of patients had a $50 \%$ or more decrease)..$^{15}$ Gastrointestinal side effects, inhibition of testosterone production, and hepatic dysfunction (and rarely death) occurred. Metyrapone has also been used to successfully treat CD patients. ${ }^{47}$ Metyrapone has also been associated with gastrointestinal side effects and may exacerbate hypertension/hirsutism by blocking 21-hydroxylase and increasing precursors to cortisol that have mineralocorticoid and androgenic activity. As a result, ketoconazole may be better suited to women and metyrapone to men. Rarely, parental etomidate (anes- thetic induction agent) was used in refractory cases to rapidly reduce supraphysiological cortisol levels but requires careful dose-titration. ${ }^{91}$

\section{Corticotroph-Directed Agents}

Pasireotide and cabergoline can inhibit ACTH production via binding to somatostatin and dopamine receptors expressed on corticotroph adenomas. Recently, pasireotide was found effective in reducing urine free cortisol levels (median 50\% reduction) and associated clinical features. ${ }^{32}$ Common side effects included gastrointestinal symptoms, gallstones, and hyperglycemia..$^{23}$ The latter occurred in approximately $75 \%$ of patients and may limit this drug's use in patients with diabetes or glucose intolerance. Cabergoline reduces urine free cortisol levels in CD patients (40\% partial and 35\% complete response) but therapeutic escape occurs in 33\% of patients after 6 to 18 months of treatment. ${ }^{84}$ Treatment was well tolerated and hypotension was the only serious side effect (13\%). Steroidogenesis inhibitors have also been combined with these corticotroph-directed agents (in short-term use) to elicit biochemical control in $90 \%$ of CD patients.

\section{Glucocorticoid Receptor Antagonist}

The glucocorticoid receptor antagonist mifepristone can be used to block the peripheral effects of elevated cortisol, including hyperglycemia. While a recent study indicates that mifepristone increases ACTH (2-fold) in CD patients, short-term imaging data suggest that CD-associated adenomas do not progress on treatment. ${ }^{36}$ Because mifepristone increases ACTH and cortisol levels indirectly via peripheral glucocorticoid receptor blockade, there is no clear end point to follow regarding adequacy of the dose. Common side effects (nausea, fatigue, headache, and hypokalemia) are typically well tolerated and reversible, ${ }^{35}$ but antiovulatory and abortifacient effects may preclude use in women who desire pregnancy.

\section{Radiation Therapy}

Radiation therapy has been used for treatment of patients with $C D$ for several decades. Radiation therapy was a mainstay of treatment when the source of CD was originally being elucidated. More recently, stereotactic radiosurgery (SRS) approaches (i.e., Gamma Knife, linear accelerator, proton beam) that precisely target the region of treatment have been introduced. The optimal dose is 20-25 Gy for SRS and 45-50.4 Gy given over 5 weeks for radiation therapy. ${ }^{85,98}$ Generally, the incidence of remission in CD seems to be similar between the various forms of radiosurgery $(43 \%-58 \%)$ and fractionated therapies (46\%-84\%; Table 3), ${ }^{13,30,85,94,98,108,109}$ but the pace of the therapeutic response may be faster with SRS. The major risk of SRS or fractionated irradiation therapy is loss of pituitary function, which is presumably the net effect of surgery and radiation. Loss of pituitary function occurs in about $20 \%-40 \%$ of patients at 10 years after radiation therapy and increases thereafter. The principal advantage of the SRS approaches over fractionated radiation methods is that they can be delivered in one session of therapy, rather than over several weeks. 
TABLE 3. Radiation results for Cushing's disease based on recent reports

\begin{tabular}{llcccc}
\hline \multicolumn{1}{c}{ Authors \& Year } & \multicolumn{1}{c}{ Technique } & No. of Patients & Follow-Up (yrs) & Margin Dose (Gy) & Biochemical Remission \\
\hline Sheehan et al., 2013 & Gamma Knife & 96 & 48 & 22 & $70 \%$ \\
\hline Wattson et al., 2014 & Proton beam & 74 & 52 & 20 & $54 \%$ \\
\hline Wilson et al., 2014 & Linear accelerator & 36 & 66 & 20 & $22 \%$ \\
\hline Budyal et al., 2014 & Fractionated & 20 & 48 & 45 (25 fractions) & $75 \%$ \\
\hline
\end{tabular}

\section{Adrenalectomy}

Because the adrenal cortices are the target organs of ACTH and the source of supraphysiological cortisol secretion in $\mathrm{CD}$, bilateral adrenalectomy can be used to treat refractory cases of $\mathrm{CD}$. Adrenalectomy is typically performed laparoscopically and produces biochemical remission in greater than $95 \%$ of refractory cases of $\mathrm{CD}$. Bilateral adrenalectomy is associated with an $18 \%$ median morbidity rate within 30 days of surgery. There is a $28 \%$ median rate of adrenal crisis after bilateral adrenalectomy. Mortality associated with bilateral adrenalectomy has been estimated at $9 \%$ and is most frequently due to stroke and myocardial infarction..$^{90}$

There is a $21 \%$ median rate of Nelson's syndrome (pituitary adenoma progression with progressive elevation of ACTH due to lack of cortisol negative feedback) after bilateral adrenalectomy. ${ }^{67,68,90}$ Early data suggest the incidence and severity of Nelson's syndrome is minimized by precedent postoperative (after pituitary surgery) radiation. ${ }^{48,63}$ Nelson's syndrome can be treated by observation (for stable small tumors), tumor resection, tumor/sella radiation, and/or pharmacotherapy. Typically, resection of pituitary adenoma or hypophysectomy is the treatment of choice. If surgery is ineffective or not possible, tumor/sella radiotherapy or radiosurgery can be performed. Finally, pharmacotherapy is used as an adjunct to treat Nelson's syndrome..$^{79}$

\section{Conclusions}

Increased understanding and improved diagnostic paradigms have enhanced detection and diagnosis of CD. Today, most CD patients can be cured by surgery or successfully managed by surgery combined with adjuvant therapies.

\section{References}

1. Alahmadi H, Cusimano MD, Woo K, Mohammed AA, Goguen J, Smyth HS, et al: Impact of technique on Cushing disease outcome using strict remission criteria. Can J Neurol Sci 40:334-341, 2013

2. Alexandraki KI, Kaltsas GA, Isidori AM, Storr HL, Afshar $\mathrm{F}$, Sabin I, et al: Long-term remission and recurrence rates in Cushing's disease: predictive factors in a single-centre study. Eur J Endocrinol 168:639-648, 2013

3. Alwani RA, de Herder WW, van Aken MO, van den Berge JH, Delwel EJ, Dallenga AH, et al: Biochemical predictors of outcome of pituitary surgery for Cushing's disease. Neuroendocrinology 91:169-178, 2010

4. Andela CD, van Haalen FM, Ragnarsson O, Papakokkinou E, Johannsson G, Santos A, et al: Mechanisms in endocrinology: Cushing's syndrome causes irreversible effects on the human brain: a systematic review of structural and functional magnetic resonance imaging studies. Eur J Endocrinol 173:R1-R14, 2015

5. Aranda G, Ensenat J, Mora M, Puig-Domingo M, Martinez de Osaba MJ, Casals G, et al: Long-term remission and recurrence rate in a cohort of Cushing's disease: the need for long-term follow-up. Pituitary 18:142-149, 2015

6. Arnaldi G, Angeli A, Atkinson AB, Bertagna X, Cavagnini F, Chrousos GP, et al: Diagnosis and complications of Cushing's syndrome: a consensus statement. J Clin Endocrinol Metab 88:5593-5602, 2003

7. Batista D, Courkoutsakis NA, Oldfield EH, Griffin KJ, Keil M, Patronas NJ, et al: Detection of adrenocorticotropinsecreting pituitary adenomas by magnetic resonance imaging in children and adolescents with Cushing disease. J Clin Endocrinol Metab 90:5134-5140, 2005

8. Berker M, Işikay I, Berker D, Bayraktar M, Gürlek A: Early promising results for the endoscopic surgical treatment of Cushing's disease. Neurosurg Rev [epub ahead of print], 2013

9. Bertagna X, Guignat L: Approach to the Cushing's disease patient with persistent/recurrent hypercortisolism after pituitary surgery. J Clin Endocrinol Metab 98:1307-1318, 2013

10. Biller BM, Grossman AB, Stewart PM, Melmed S, Bertagna $\mathrm{X}$, Bertherat J, et al: Treatment of adrenocorticotropindependent Cushing's syndrome: a consensus statement. J Clin Endocrinol Metab 93:2454-2462, 2008

11. Bochicchio D, Losa M, Buchfelder M: Factors influencing the immediate and late outcome of Cushing's disease treated by transsphenoidal surgery: a retrospective study by the European Cushing's Disease Survey Group. J Clin Endocrinol Metab 80:3114-3120, 1995

12. Brown RD, Van Loon GR, Orth DN, Liddle GW: Cushing's disease with periodic hormonogenesis: one explanation for paradoxical response to dexamethasone. J Clin Endocrinol Metab 36:445-451, 1973

13. Budyal S, Lila AR, Jalali R, Gupta T, Kasliwal R, Jagtap VS, et al: Encouraging efficacy of modern conformal fractionated radiotherapy in patients with uncured Cushing's disease. Pituitary 17:60-67, 2014

14. Carrasco CA, Coste J, Guignat L, Groussin L, Dugué MA, Gaillard S, et al: Midnight salivary cortisol determination for assessing the outcome of transsphenoidal surgery in Cushing's disease. J Clin Endocrinol Metab 93:47284734, 2008

15. Castinetti F, Guignat L, Giraud P, Muller M, Kamenicky P, Drui D, et al: Ketoconazole in Cushing's disease: is it worth a try? J Clin Endocrinol Metab 99:1623-1630, 2014

16. Castinetti F, Morange I, Dufour H, Jaquet P, Conte-Devolx B, Girard N, et al: Desmopressin test during petrosal sinus sampling: a valuable tool to discriminate pituitary or ectopic ACTH-dependent Cushing's syndrome. Eur J Endocrinol 157:271-277, 2007

17. Chang AC, Cochet M, Cohen SN: Structural organization of human genomic DNA encoding the pro-opiomelanocortin peptide. Proc Natl Acad Sci U S A 77:4890-4894, 1980

18. Chowdhury IN, Sinaii N, Oldfield EH, Patronas N, Nieman LK: A change in pituitary magnetic resonance imaging protocol detects ACTH-secreting tumours in patients with 
previously negative results. Clin Endocrinol (Oxf) 72:502506, 2010

19. Chrousos GP, Schulte HM, Oldfield EH, Gold PW, Cutler GB Jr, Loriaux DL: The corticotropin-releasing factor stimulation test. An aid in the evaluation of patients with Cushing's syndrome. N Engl J Med 310:622-626, 1984

20. Ciric I, Zhao JC, Du H, Findling JW, Molitch ME, Weiss RE, et al: Transsphenoidal surgery for Cushing disease: experience with 136 patients. Neurosurgery 70:70-81, 2012

21. Clayton RN, Raskauskiene D, Reulen RC, Jones PW: Mortality and morbidity in Cushing's disease over 50 years in Stoke-on-Trent, UK: audit and meta-analysis of literature. J Clin Endocrinol Metab 96:632-642, 2011

22. Colao A, Bronstein MD, Freda P, Gu F, Shen CC, Gadelha $\mathrm{M}$, et al: Pasireotide versus octreotide in acromegaly: a head-to-head superiority study. J Clin Endocrinol Metab 99:791-799, 2014

23. Colao A, Pivonello R, Spiezia S, Faggiano A, Ferone D, Filippella M, et al: Persistence of increased cardiovascular risk in patients with Cushing's disease after five years of successful cure. J Clin Endocrinol Metab 84:2664-2672, 1999

24. Costenaro F, Rodrigues TC, Rollin GA, Ferreira NP, Czepielewski MA: Evaluation of Cushing's disease remission after transsphenoidal surgery based on early serum cortisol dynamics. Clin Endocrinol (Oxf) 80:411-418, 2014

25. Dallapiazza RF, Oldfield EH, Jane JA Jr: Surgical management of Cushing's disease. Pituitary 18:211-216, 2015

26. Dickerman RD, Oldfield EH: Basis of persistent and recurrent Cushing disease: an analysis of findings at repeated pituitary surgery. J Neurosurg 97:1343-1349, 2002

27. Dimopoulou C, Schopohl J, Rachinger W, Buchfelder M, Honegger J, Reincke M, et al: Long-term remission and recurrence rates after first and second transsphenoidal surgery for Cushing's disease: care reality in the Munich Metropolitan Region. Eur J Endocrinol 170:283-292, 2014

28. Doppman JL, Oldfield E, Krudy AG, Chrousos GP, Schulte HM, Schaaf M, et al: Petrosal sinus sampling for Cushing syndrome: anatomical and technical considerations. Work in progress. Radiology 150:99-103, 1984

29. Esposito F, Dusick JR, Cohan P, Moftakhar P, McArthur D, Wang C, et al: Clinical review: Early morning cortisol levels as a predictor of remission after transsphenoidal surgery for Cushing's disease. J Clin Endocrinol Metab 91:7-13, 2006

30. Estrada J, Boronat M, Mielgo M, Magallón R, Millan I, Díez S, et al: The long-term outcome of pituitary irradiation after unsuccessful transsphenoidal surgery in Cushing's disease. N Engl J Med 336:172-177, 1997

31. Etxabe J, Vazquez JA: Morbidity and mortality in Cushing's disease: an epidemiological approach. Clin Endocrinol (Oxf) 40:479-484, 1994

32. Feelders RA, de Herder WW, Neggers SJ, van der Lely AJ, Hofland LJ: Pasireotide, a multi-somatostatin receptor ligand with potential efficacy for treatment of pituitary and neuroendocrine tumors. Drugs Today (Barc) 49:89-103, 2013

33. Findling JW, Kehoe ME, Raff H: Identification of patients with Cushing's disease with negative pituitary adrenocorticotropin gradients during inferior petrosal sinus sampling: prolactin as an index of pituitary venous effluent. J Clin Endocrinol Metab 89:6005-6009, 2004

34. Findling JW, Kehoe ME, Shaker JL, Raff H: Routine inferior petrosal sinus sampling in the differential diagnosis of adrenocorticotropin (ACTH)-dependent Cushing's syndrome: early recognition of the occult ectopic ACTH syndrome. J Clin Endocrinol Metab 73:408-413, 1991

35. Fleseriu M, Biller BM, Findling JW, Molitch ME,
Schteingart DE, Gross C: Mifepristone, a glucocorticoid receptor antagonist, produces clinical and metabolic benefits in patients with Cushing's syndrome. J Clin Endocrinol Metab 97:2039-2049, 2012

36. Fleseriu M, Findling JW, Koch CA, Schlaffer SM, Buchfelder M, Gross C: Changes in plasma ACTH levels and corticotroph tumor size in patients with Cushing's disease during long-term treatment with the glucocorticoid receptor antagonist mifepristone. J Clin Endocrinol Metab 99:3718-3727, 2014

37. Forget H, Lacroix A, Cohen H: Persistent cognitive impairment following surgical treatment of Cushing's syndrome. Psychoneuroendocrinology 27:367-383, 2002

38. Gandhi CD, Meyer SA, Patel AB, Johnson DM, Post KD Neurologic complications of inferior petrosal sinus sampling. AJNR Am J Neuroradiol 29:760-765, 2008

39. Gicquel C, Le Bouc Y, Luton JP, Girard F, Bertagna X: Monoclonality of corticotroph macroadenomas in Cushing's disease. J Clin Endocrinol Metab 75:472-475, 1992

40. Graversen D, Vestergaard P, Stochholm K, Gravholt CH, Jørgensen JO: Mortality in Cushing's syndrome: a systematic review and meta-analysis. Eur J Intern Med 23:278282,2012

41. Hameed N, Yedinak CG, Brzana J, Gultekin SH, Coppa ND, Dogan A, et al: Remission rate after transsphenoidal surgery in patients with pathologically confirmed Cushing's disease, the role of cortisol, ACTH assessment and immediate reoperation: a large single center experience. Pituitary 16:452-458, 2013

42. Hammer GD, Tyrrell JB, Lamborn KR, Applebury CB, Hannegan ET, Bell S, et al: Transsphenoidal microsurgery for Cushing's disease: initial outcome and long-term results. J Clin Endocrinol Metab 89:6348-6357, 2004

43. Hermus AR, Pieters GF, Pesman GJ, Smals AG, Benraad TJ, Kloppenborg PW: The corticotropin-releasing-hormone test versus the high-dose dexamethasone test in the differential diagnosis of Cushing's syndrome. Lancet 2:540-544, 1986

44. Honegger J, Schmalisch K, Beuschlein F, Kaufmann S, Schnauder G, Naegele T, et al: Contemporary microsurgical concept for the treatment of Cushing's disease: endocrine outcome in 83 consecutive patients. Clin Endocrinol (Oxf) 76:560-567, 2012

45. Invitti C, Pecori Giraldi F, de Martin M, Cavagnini F: Diagnosis and management of Cushing's syndrome: results of an Italian multicentre study. J Clin Endocrinol Metab 84:440-448, 1999

46. Jagannathan J, Smith R, DeVroom HL, Vortmeyer AO, Stratakis CA, Nieman LK, et al: Outcome of using the histological pseudocapsule as a surgical capsule in Cushing disease. J Neurosurg 111:531-539, 2009

47. Jeffcoate WJ, Rees LH, Tomlin S, Jones AE, Edwards CR, Besser GM: Metyrapone in long-term management of Cushing's disease. BMJ 2:215-217, 1977

48. Jenkins PJ, Trainer PJ, Plowman PN, Shand WS, Grossman AB, Wass JA, et al: The long-term outcome after adrenalectomy and prophylactic pituitary radiotherapy in adrenocorticotropin-dependent Cushing's syndrome. J Clin Endocrinol Metab 80:165-171, 1995

49. Kaltsas GA, Giannulis MG, Newell-Price JD, Dacie JE, Thakkar C, Afshar F, et al: A critical analysis of the value of simultaneous inferior petrosal sinus sampling in Cushing's disease and the occult ectopic adrenocorticotropin syndrome. J Clin Endocrinol Metab 84:487-492, 1999

50. Kanter AS, Diallo AO, Jane JA Jr, Sheehan JP, Asthagiri AR, Oskouian RJ, et al: Single-center experience with pediatric Cushing's disease. J Neurosurg 103 (5 Suppl):413420, 2005

51. Kelly WF: Psychiatric aspects of Cushing's syndrome. QJM 89:543-551, 1996 
52. Kronenberg HM, Melmed S, Polonsky KS, Larsen PR (eds): Williams Textbook of Endocrinology, ed 11. Philadelphia: Saunders Elsevier, 2008

53. Lambert JK, Goldberg L, Fayngold S, Kostadinov J, Post KD, Geer EB: Predictors of mortality and long-term outcomes in treated Cushing's disease: a study of 346 patients. J Clin Endocrinol Metab 98:1022-1030, 2013

54. Liddle GW: Tests of pituitary-adrenal suppressibility in the diagnosis of Cushing's syndrome. J Clin Endocrinol Metab 20:1539-1560, 1960

55. Lindholm J, Juul S, Jørgensen JO, Astrup J, Bjerre P, Feldt-Rasmussen U, et al: Incidence and late prognosis of Cushing's syndrome: a population-based study. J Clin Endocrinol Metab 86:117-123, 2001

56. Lindsay JR, Oldfield EH, Stratakis CA, Nieman LK: The postoperative basal cortisol and CRH tests for prediction of long-term remission from Cushing's disease after transsphenoidal surgery. J Clin Endocrinol Metab 96:2057-2064, 2011

57. Lonser RR, Ksendzovsky A, Wind JJ, Vortmeyer AO, Oldfield EH: Prospective evaluation of the characteristics and incidence of adenoma-associated dural invasion in Cushing disease. J Neurosurg 116:272-279, 2012

58. Lonser RR, Wind JJ, Nieman LK, Weil RJ, DeVroom HL, Oldfield EH: Outcome of surgical treatment of 200 children with Cushing's disease. J Clin Endocrinol Metab 98:892901, 2013

59. Machado MC, de Sa SV, Domenice S, Fragoso MC, Puglia $\mathrm{P} \mathrm{Jr}$, Pereira MA, et al: The role of desmopressin in bilateral and simultaneous inferior petrosal sinus sampling for differential diagnosis of ACTH-dependent Cushing's syndrome. Clin Endocrinol (Oxf) 66:136-142, 2007

60. Magiakou MA, Mastorakos G, Oldfield EH, Gomez MT, Doppman JL, Cutler GB Jr, et al: Cushing's syndrome in children and adolescents. Presentation, diagnosis, and therapy. N Engl J Med 331:629-636, 1994

61. Manni A, Latshaw RF, Page R, Santen RJ: Simultaneous bilateral venous sampling for adrenocorticotropin in pituitary-dependent Cushing's disease: evidence for lateralization of pituitary venous drainage. J Clin Endocrinol Metab 57:1070-1073, 1983

62. Mehta GU, Lonser RR, Oldfield EH: The history of pituitary surgery for Cushing disease. J Neurosurg 116:261268, 2012

63. Mehta GU, Sheehan JP, Vance ML: Effect of stereotactic radiosurgery before bilateral adrenalectomy for Cushing's disease on the incidence of Nelson's syndrome. J Neurosurg 119:1493-1497, 2013

64. Miller DL, Doppman JL, Peterman SB, Nieman LK, Oldfield EH, Chang R: Neurologic complications of petrosal sinus sampling. Radiology 185:143-147, 1992

65. Mulligan GB, Faiman C, Gupta M, Kennedy L, Hatipoglu $\mathrm{B}$, Hui F, et al: Prolactin measurement during inferior petrosal sinus sampling improves the localization of pituitary adenomas in Cushing's disease. Clin Endocrinol (Oxf) 77:268-274, 2012

66. Nakanishi S, Inoue A, Kita T, Nakamura M, Chang AC, Cohen SN, et al: Nucleotide sequence of cloned cDNA for bovine corticotropin-beta-lipotropin precursor. Nature 278:423-427, 1979

67. Nelson DH, Meakin JW, Dealy JB Jr, Matson DD, Emerson $\mathrm{K} \mathrm{Jr}$, Thorn GW: ACTH-producing tumor of the pituitary gland. N Engl J Med 259:161-164, 1958

68. Nelson DH, Meakin JW, Thorn GW: ACTH-producing pituitary tumors following adrenalectomy for Cushing's syndrome. Ann Intern Med 52:560-569, 1960

69. Newell-Price J, Bertagna X, Grossman AB, Nieman LK: Cushing's syndrome. Lancet 367:1605-1617, 2006

70. Newell-Price J, Trainer P, Besser M, Grossman A: The diagnosis and differential diagnosis of Cushing's syndrome and pseudo-Cushing's states. Endocr Rev 19:647-672, 1998

71. Nieman LK, Biller BM, Findling JW, Murad MH, NewellPrice J, Savage MO, et al: Treatment of Cushing's syndrome: an Endocrine Society Clinical practice guideline. J Clin Endocrinol Metab 100:2807-2831, 2015

72. Nieman LK, Biller BM, Findling JW, Newell-Price J, Savage MO, Stewart PM, et al: The diagnosis of Cushing's syndrome: an Endocrine Society Clinical Practice Guideline. J Clin Endocrinol Metab 93: 1526-1540, 2008

73. Nieman LK, Cutler GB Jr, Oldfield EH, Loriaux DL, Chrousos GP: The ovine corticotropin-releasing hormone (CRH) stimulation test is superior to the human CRH stimulation test for the diagnosis of Cushing's disease. J Clin Endocrinol Metab 69:165-169, 1989

74. Oldfield EH, Chrousos GP, Schulte HM, Schaaf M, McKeever PE, Krudy AG, et al: Preoperative lateralization of ACTH-secreting pituitary microadenomas by bilateral and simultaneous inferior petrosal venous sinus sampling. $\mathbf{N}$ Engl J Med 312:100-103, 1985

75. Oldfield EH, Doppman JL, Nieman LK, Chrousos GP, Miller DL, Katz DA, et al: Petrosal sinus sampling with and without corticotropin-releasing hormone for the differential diagnosis of Cushing's syndrome. N Engl J Med 325:897905, 1991

76. Oldfield EH, Vance ML, Louis RG, Pledger CL, Jane JA $\mathrm{Jr}$, Lopes MB: Crooke's changes in Cushing's syndrome depends on degree of hypercortisolism and individual susceptibility. J Clin Endocrinol Metab 100:3165-3171, 2015

77. Oldfield EH, Vortmeyer AO: Development of a histological pseudocapsule and its use as a surgical capsule in the excision of pituitary tumors. J Neurosurg 104:7-19, 2006

78. Orth DN, DeBold CR, DeCherney GS, Jackson RV, Sheldon WR Jr, Nicholson WE, et al: Clinical studies with synthetic ovine corticotropin-releasing factor. Fed Proc 44:197-202, 1985

79. Patel J, Eloy JA, Liu JK: Nelson's syndrome: a review of the clinical manifestations, pathophysiology, and treatment strategies. Neurosurg Focus 38(2):E14, 2015

80. Patil CG, Prevedello DM, Lad SP, Vance ML, Thorner MO, Katznelson L, et al: Late recurrences of Cushing's disease after initial successful transsphenoidal surgery. J Clin Endocrinol Metab 93:358-362, 2008

81. Patronas N, Bulakbasi N, Stratakis CA, Lafferty A, Oldfield $\mathrm{EH}$, Doppman J, et al: Spoiled gradient recalled acquisition in the steady state technique is superior to conventional postcontrast spin echo technique for magnetic resonance imaging detection of adrenocorticotropin-secreting pituitary tumors. J Clin Endocrinol Metab 88:1565-1569, 2003

82. Pecori Giraldi F, Moro M, Cavagnini F: Gender-related differences in the presentation and course of Cushing's disease. J Clin Endocrinol Metab 88:1554-1558, 2003

83. Peytremann A, Nicholson WE, Brown RD, Liddle GW, Hardman JG: Comparative effects of angiotensin and ACTH on cyclic AMP and steroidogenesis in isolated bovine adrenal cells. J Clin Invest 52:835-842, 1973

84. Pivonello R, De Martino MC, Cappabianca P, De Leo M, Faggiano A, Lombardi G, et al: The medical treatment of Cushing's disease: effectiveness of chronic treatment with the dopamine agonist cabergoline in patients unsuccessfully treated by surgery. J Clin Endocrinol Metab 94:223-230, 2009

85. Pouratian N, Prevedello DM, Jagannathan J, Lopes MB, Vance ML, Laws ER Jr: Outcomes and management of patients with Cushing's disease without pathological confirmation of tumor resection after transsphenoidal surgery. J Clin Endocrinol Metab 92:3383-3388, 2007

86. Prevedello DM, Pouratian N, Sherman J, Jane JA Jr, Vance 
ML, Lopes MB, et al: Management of Cushing's disease: outcome in patients with microadenoma detected on pituitary magnetic resonance imaging. J Neurosurg 109:751759,2008

87. Ragnarsson O, Berglund P, Eder DN, Johannsson G: Long-term cognitive impairments and attentional deficits in patients with Cushing's disease and cortisol-producing adrenal adenoma in remission. J Clin Endocrinol Metab 97:E1640-E1648, 2012

88. Ram Z, Nieman LK, Cutler GB Jr, Chrousos GP, Doppman JL, Oldfield EH: Early repeat surgery for persistent Cushing's disease. J Neurosurg 80:37-45, 1994

89. Ratliff JK, Oldfield EH: Multiple pituitary adenomas in Cushing's disease. J Neurosurg 93:753-761, 2000

90. Ritzel K, Beuschlein F, Mickisch A, Osswald A, Schneider HJ, Schopohl J, et al: Clinical review: Outcome of bilateral adrenalectomy in Cushing's syndrome: a systematic review. J Clin Endocrinol Metab 98:3939-3948, 2013

91. Schulte HM, Benker G, Reinwein D, Sippell WG, Allolio $\mathrm{B}$ : Infusion of low dose etomidate: correction of hypercortisolemia in patients with Cushing's syndrome and doseresponse relationship in normal subjects. J Clin Endocrinol Metab 70:1426-1430, 1990

92. Semple PL, Vance ML, Findling J, Laws ER Jr: Transsphenoidal surgery for Cushing's disease: outcome in patients with a normal magnetic resonance imaging scan. Neurosurgery 46:553-559, 2000

93. Sharma ST, Raff H, Nieman LK: Prolactin as a marker of successful catheterization during IPSS in patients with ACTH-dependent Cushing's syndrome. J Clin Endocrinol Metab 96:3687-3694, 2011

94. Sheehan JP, Xu Z, Salvetti DJ, Schmitt PJ, Vance ML: Results of Gamma Knife surgery for Cushing's disease. J Neurosurg 119:1486-1492, 2013

95. Sherlock M, Fernandez-Rodriguez E, Alonso AA, Reulen $\mathrm{RC}$, Ayuk J, Clayton RN, et al: Medical therapy in patients with acromegaly: predictors of response and comparison of efficacy of dopamine agonists and somatostatin analogues. J Clin Endocrinol Metab 94:1255-1263, 2009

96. Sheth SA, Mian MK, Neal J, Tritos NA, Nachtigall L, Klibanski A, et al: Transsphenoidal surgery for Cushing disease after nondiagnostic inferior petrosal sinus sampling. Neurosurgery 71:14-22, 2012

97. Starke RM, Reames DL, Chen CJ, Laws ER, Jane JA Jr: Endoscopic transsphenoidal surgery for Cushing disease: techniques, outcomes, and predictors of remission. Neurosurgery 72:240-247, 2013

98. Starke RM, Williams BJ, Vance ML, Sheehan JP: Radiation therapy and stereotactic radiosurgery for the treatment of Cushing's disease: an evidence-based review. Curr Opin Endocrinol Diabetes Obes 17:356-364, 2010

99. Storr HL, Alexandraki KI, Martin L, Isidori AM, Kaltsas GA, Monson JP, et al: Comparisons in the epidemiology, diagnostic features and cure rate by transsphenoidal surgery between paediatric and adult-onset Cushing's disease. Eur J Endocrinol 164:667-674, 2011

100. Styne DM, Grumbach MM, Kaplan SL, Wilson CB, Conte FA: Treatment of Cushing's disease in childhood and adolescence by transsphenoidal microadenomectomy. N Engl J Med 310:889-893, 1984

101. Sun Y, Sun Q, Fan C, Shen J, Zhao W, Guo Y, et al: Diagnosis and therapy for Cushing's disease with negative dynamic MRI finding: a single-centre experience. Clin Endocrinol (Oxf) 76:868-876, 2012

102. Swearingen B, Biller BM, Barker FG II, Katznelson L, Grinspoon S, Klibanski A, et al: Long-term mortality after transsphenoidal surgery for Cushing disease. Ann Intern Med 130:821-824, 1999

103. Terzolo M, Allasino B, Pia A, Peraga G, Daffara F, Laino
F, et al: Surgical remission of Cushing's syndrome reduces cardiovascular risk. Eur J Endocrinol 171:127-136, 2014

104. Tindall GT, Herring CJ, Clark RV, Adams DA, Watts NB: Cushing's disease: results of transsphenoidal microsurgery with emphasis on surgical failures. J Neurosurg 72:363369,1990

105. Tjörnstrand A, Gunnarsson K, Evert M, Holmberg E, Ragnarsson O, Rosén T, et al: The incidence rate of pituitary adenomas in western Sweden for the period 20012011. Eur J Endocrinol 171:519-526, 2014

106. Vale W, Vaughan J, Smith M, Yamamoto G, Rivier J, Rivier C: Effects of synthetic ovine corticotropin-releasing factor, glucocorticoids, catecholamines, neurohypophysial peptides, and other substances on cultured corticotropic cells. Endocrinology 113:1121-1131, 1983

107. Wagenmakers MA, Boogaarts HD, Roerink SH, Timmers HJ, Stikkelbroeck NM, Smit JW, et al: Endoscopic transsphenoidal pituitary surgery: a good and safe primary treatment option for Cushing's disease, even in case of macroadenomas or invasive adenomas. Eur J Endocrinol 169:329-337, 2013

108. Wattson DA, Tanguturi SK, Spiegel DY, Niemierko A, Biller BM, Nachtigall LB, et al: Outcomes of proton therapy for patients with functional pituitary adenomas. Int $\mathbf{J}$ Radiat Oncol Biol Phys 90:532-539, 2014

109. Wilson PJ, Williams JR, Smee RI: Cushing's disease: a single centre's experience using the linear accelerator (LINAC) for stereotactic radiosurgery and fractionated stereotactic radiotherapy. J Clin Neurosci 21:100-106, 2014

110. Wind JJ, Lonser RR, Nieman LK, DeVroom HL, Chang R, Oldfield EH: The lateralization accuracy of inferior petrosal sinus sampling in 501 patients with Cushing's disease. J Clin Endocrinol Metab 98:2285-2293, 2013

111. Yaneva M, Kalinov K, Zacharieva S: Mortality in Cushing's syndrome: data from 386 patients from a single tertiary referral center. Eur J Endocrinol 169:621-627, 2013

112. Yanovski JA, Cutler GB Jr, Doppman JL, Miller DL, Chrousos GP, Oldfield EH, et al: The limited ability of inferior petrosal sinus sampling with corticotropin-releasing hormone to distinguish Cushing's disease from pseudoCushing states or normal physiology. J Clin Endocrinol Metab 77:503-509, 1993

113. Zilio M, Barbot M, Ceccato F, Camozzi V, Bilora F, Casonato A, et al: Diagnosis and complications of Cushing's disease: gender-related differences. Clin Endocrinol (Oxf) 80:403-410, 2014

\section{Disclosures}

The authors report no conflict of interest concerning the materials or methods used in this study or the findings specified in this paper.

\section{Author Contributions}

Conception and design: Lonser, Oldfield. Acquisition of data: all authors. Analysis and interpretation of data: all authors. Drafting the article: all authors. Critically revising the article: all authors. Reviewed submitted version of manuscript: all authors. Approved the final version of the manuscript on behalf of all authors: Lonser. Administrative/technical/material support: Lonser, Oldfield. Study supervision: all authors.

\section{Correspondence}

Russell R. Lonser, Department of Neurological Surgery, The Ohio State University Wexner Medical Center, 410 W 10th Ave., Doan Hall N1047, Columbus, OH 43210. email: russell.lonser@ osumc.edu. 